\title{
ENTOMOPATHOGENIC NEMATODES AS BIOINSECTICIDES - A REVIEW
}

\author{
SIKANDAR, A. ${ }^{1}$ - YUAN, R. H. ${ }^{2}$ - LIAN, X. L. ${ }^{2}$ - ZHEN, M. A. ${ }^{2}-$ ZHAO, P. ${ }^{3}-$ LI, F. ${ }^{4}-$ LU, X. P. ${ }^{5}-$ \\ WANG, Y. Y. ${ }^{1.2^{*}}$ \\ ${ }^{I}$ Nematology Institute of Northern China, Shenyang Agricultural University, Shenyang 110866, \\ Liaoning, China \\ ${ }^{2}$ College of Biosciences and Biotechnology, Shenyang Agricultural University, Shenyang \\ 110866, Liaoning, China \\ ${ }^{3}$ College of Plant Protection, Shenyang Agricultural University, Liaoning, People Republic of \\ China
}

${ }^{4}$ Chifeng Academy of Agricultural and Animal Husbandry Sciences, Chifeng, Inner Mongolia, People Republic of China

${ }^{5}$ Liaoning Agricultural Development Service Center, Shenyang, Liaoning, People Republic of China

${ }^{*}$ Corresponding author

e-mail: wyuanyuan1225@syau.edu.cn; phone: +86-138-9818-2096

(Received 14 $4^{\text {th }}$ Jan 2021; accepted $18^{\text {th }}$ Mar 2021)

\begin{abstract}
Entomopathogenic nematodes (EPNs) belonging to the Heterorhabditis and Steinernema genera provide effective bio-control of insect pests. They are extremely lethal to such pests due to mutualistic association with the genera of bacteria Photorhabdus and Xenorhabdus and are safe for beneficial insects. They are used as biopesticides because they are eco-friendly with no harmful effects on human wellbeing. EPNs are well-suited with the number of agrochemicals and a cost-effective substitute for chemical insecticides. This review assesses the use of EPNs under agroclimatic conditions, the influence of abiotic factors, life cycle, trapping, production, storage, mechanisms, biopesticides and their suitable application. However, a previous study on EPNs and their role as biopesticides have been surveyed for their possible usage as biological control agents.

Keywords: Heterorhabditis, Steinernema, Photorhabdus, Xenorhabdus, agrochemicals, biological control agent
\end{abstract}

\section{Introduction}

Nematodes are roundworms, colourless microorganisms, possessing almost all schemes of higher organisms except circulatory or respiratory systems (Sikandar et al., 2019, 2020b). They may be parasitic, predaceous, or free-living and have an abundance of various associations from useful to harmful (Ferris et al., 2012). Their association can be divided into four basic groups; facultative parasitism, obligate parasitism, necromenic and phoretic (Askary et al., 2018). Entomopathogenic nematodes (EPNs) can be obligate or facultative parasites on harmful insects. They have been recorded on all continents except Antarctica (Abate et al., 2017). Entomopathogenic nematodes have a wide host range and can easily find their suitable host. Biological control is a safe way to control pests and pathogens (Sikandar et al., 2020a). They have huge consideration in the field of biological control (Davari and Parker, 2018; Trdan et al., 2020). 
Entomopathogenic nematodes are harmless or safe for non-targeted organisms (Dutka et al., 2015) and yet pose no threat to beneficial insects (Akhurst and Smith, 2002). They are eco-friendly and non-toxic to humans and can easily apply with pesticide equipment (Shapiro-Ilan et al., 2006). Steiner in 1923 described the first entomopathogenic nematode (EPNs) (Dillman, 2013).

Twenty-three families of nematodes have been recorded as a parasite of insects but the species of seven families have more potency to control insects (Shapiro-Ilan et al., 2012). Families Heterorhabditiae and Steinernematidae have been more frequently and effectively used in pest biological control (Bal and Grewal, 2017). Usually, species of genera Steinernema and Herorhabditis (Rhabditida) are used as biological control agents in the domain of plant protection (Laznik and Trdan, 2014). Species of genus Oscheius are entomopathogenic because they are also a parasite of insect pest meanwhile Steinernematidae and Heterorhabditidae received more attention as effective biocontrol agents (Dillman et al., 2012b). The symbiosis of EPNs with bacteria like Photorhabdus and Xenorhabdus can effectively control Coleopteran, Dipteran and Lepidopteran pests (Mohan, 2015).

Entomopathogenic nematodes have been divided into two categories according to their host searching behaviour including cruisers and ambushers. Cruisers such as Heterorhabditis bacterophora and Steinernema glaseri are subterranean, more active to find suitable host, while ambushers like Steinernema carpocapsae usually wait to attack suitable host in the upper surface of the soil (Mohan, 2015). They can search their host in different ways like vibration, carbon dioxide, or other chemicals (Lortkipanidze et al., 2016). They showed significant potential as natural pest control agents in the soil environment (De Brida et al., 2017). After finding a suitable host and penetrating it, they can kill the host within 1-4 days. Their killing capacity depends upon the host and nematode species.

More than $90 \%$ of insects have their life stages in the soil, so are easily exposed to EPNs (Radová, 2010). They can suppress a huge variety of commercially targeted important pests (Lacey and Georgis, 2012). Entomopathogenic nematodes can control a variety of insect species i.e. Alissonolurn impressicalla, Arbela dea, Blitoportha pallidipennis Reitter, Holotrichia parallela, Odoiporus longicollis, Otiorhynchus sulcatus, Pachraetus litus, Paranthrene tubaniformis, Phylloreta striolut, etc in China (Mahmoud, 2016). Substantial progress in the application, production and research of entomopathogenic nematodes has been made in the last decade (Lacey et al., 2015).

\section{Influence of abiotic and biotic factors}

Entomopathogenic nematodes can survive under a variety of environments but some abiotic factors influence their activity such as infectious juveniles (IJs) can survive in the value of $\mathrm{pH}$ of soil between 4-8 but their activities are minimized at a $\mathrm{pH}$ value of 10. Moisture and $\mathrm{pH}$ also influenced their occurrences (Stuart et al., 2015). During a survey on EPNs in North China, the environmental conditions imposed harmful effects on their virulence, survival, and reproduction (Ma et al., 2010). High salinity also affected the activity of EPNs (Kergunteuil et al., 2016), but it increased the rate of tolerance toward high temperatures (Hussaini, 2017).

They are distributed throughout the world and they can tolerate overwintering conditions, as reported from extreme cold Heilongjiang Province of China (Chunjie et al., 2011). Their recovery depends upon the texture and characterization of soil 
(Noosidum et al., 2010). They found usually less in clay soil due to the low oxygen value and matter contents in it. They are more frequently recovered in sandy soil (Banu, 2017). Entomopathogenic nematodes were isolated from sandy soil in South China and Beijing areas (Griffin et al., 2000).

The effects of biotic factors (like species of EPNs, soil fauna, age of targeted insects) and abiotic factors (moisture, temperature, soil type and aeration) have been reported by several researchers (Shapiro-Ilan et al., 2012). Researchers have mainly focused on their potential as inductively applied augmentative biocontrol agents (Grewal et al., 2005; Laznik et al., 2010; Laznik et al., 2011). That's why they have needed to adapt environmental conditions on application sites to become more effective biocontrol agents (Del Pino et al., 2018).

\section{Trapping of entomopathogenic nematodes}

\section{Galleria soil trap method}

The soil trap method is usually used for the extraction of EPNs. 200/250g soil was added into the plastic pots having approximately $90 \mathrm{~cm}$ diameter (Razia and Sivaramakrishnan, 2014). Five instar larvae of the greater wax moth, Galleria mellonella $\mathrm{L}$. were placed into each pot and covered for incubation of five to seven days at $27-30^{\circ} \mathrm{C}$. From the second day onwards, dead larvae were examined and removed regularly. The dead larvae were rinsed with water and dissected into Ringer's solution to collect the entomopathogenic nematodes.

\section{White trap method}

The white trap method is used to collect IJs from cadaver insects. Following this method, dead insects were placed into the white trap for three to four weeks until all juveniles emerged out from the cadaver. Usually, a plastic container was used for this method and filled with distilled water up to $1 \mathrm{~cm}$. The bottom of the inverted Petri dish was placed in the container and the juveniles that emerged out were collected (White, 1927).

\section{Life cycle}

Heterorhabditis and Steinernema have similar life stages. These nematodes have a high reproduction rate and can easily culture in lab conditions. They have a chemoreceptor that can detect their host easily and kill them quickly. They are parasitic completely in all stages outside the host except the dauer stage (Onstad et al., 2006). Dauer juvenile is a special developmental stage of all rhabditids. The term dauer is a German word meaning enduring (Fuchs, 1915). It is an infective of these nematodes (Susurluk and Ehlers, 2008). The free-living infective stage is only one stage of their cycle that can exist outside of the host (Spence et al., 2011). Once they find their suitable host they can easily enter into it (Andaló et al., 2017).

Infectious juveniles penetrate the host through the opening including the anus, breathing pore, mouth, spiracles, and pores in cuticles (De Siqueira Sabino et al., 2014) while S. glaseri entered into the host through body openings (Hoctor et al., 2012). Mostly their penetration into the host through breathing pore (Fujimoto et al., 2007). 
The relationship between entomopathogenic nematode and entomopathogenic bacteria is highly specific; bacteria Photorhabdus spp. and Xenorhabdus spp. are associated with Heterorhabditis and Steinernema, respectively (Ferreira and Malan, 2014). Entomopathogenic nematodes with their symbiotic bacteria can efficiently suppress insect pests in cryptic and soil habitats (Divya and Sankar, 2009). These bacteria entirely depend upon nematodes as a vector from one host to another as well as nematodes immune system of the host (Lewis and Clarke, 2012). The bacteria are rapidly reproduced within the insect and kill it within 24-48 hours, and nematodes are feed on it and complete their life stages (Adams and Nguyen, 2002).

In Heterorhabditis infectious juveniles become hermaphroditic adults but their nextgeneration is produced by males and females while in Steinernema all generations are produced by males and females (Grewal et al., 2005). After continuously feeding upon cadaver of insect the second stage juveniles develop into third stage juveniles at that time they leave the insect cadaver for searching new living hosts (Jagdale et al., 2005). The insect cadaver turns into tan or brown if Steinernematids killed it whereas it becomes red when Heterorhabditids killed it, these pigmentations depend upon the mutualistic bacteria (Yadav, 2012).

\section{Production}

Entomopathogenic nematodes are produced by a different method in vitro or in vivo by liquid and solid culture (Shapiro-Ilan et al., 2012). In vitro production, the dauer juveniles are the only stage of entomopathogenic nematode that is used commercially. Culturing is based upon introducing nematodes in a nutrition medium with a pure culture of their symbiotic bacteria. Bedding three-dimensional productions have been the most successful method in solid culture for the production of Heterorhabditis and Steinernema (Shapiro-Ilan et al., 2012). Large fermentation units are used for the production of these nematodes in large quantities for commercial use.

The liquid culture method is a more cost-efficient process than solid culture for the commercial market. However, it also demands a high level of technical expertise and capital investment (Shapiro-Ilan et al., 2012). Advancement in liquid culture is necessary to improve efficiency and quality of production through different processes like optimizing bioprocess and media kinetics (Chavarría-Hernández et al., 2010), improving inoculum and its timing and density of bacterial cells (Hirao and Ehlers, 2010), improving useful traits such as desiccation and heat tolerance in Heterorhabditis and downstream processing (Anbesse et al., 2013).

In in vitro liquid culture, EPNs have produced continuously at a high level of efficacy with improvement in media, bioreactor design, and other parameters (Chavarría-Hernández et al., 2010). In in vivo production, culturing of EPNs in hosts is a simple process because it requires less technology. Galleria mellonella (L.) is the most common insect used for commercial and laboratory EPN cultures whereas Tenebrio molitor L. was also used for EPNs production (Shapiro-Ilan et al., 2002). Other hosts have been studied for culturing them, including beet armyworm Spodoptera exigua (Hübner), cabbage looper Trichoplusia ni (Hübner), corn earworm Helicoverpa zea (Boddie), house cricket Acheta domesticus (L.), gypsy moth Lymantria dispar (L.), orange worm Ameylois transitella (Walker), pink bollworm Pectinophora gossypiella (Saunders), tobacco budworm Heliothis virescens (F.) and various battles (Shapiro-Ilan et al., 2012). 
White trap method is used for natural escape of EPNs from a host cadaver. This method is ideal for laboratory studies or small markets because of cost-effective production (Shapiro-Ilan et al., 2002). In vivo production is a two-dimensional system based on production in shelves and trays (Ehlers and Shapiro-Ilan, 2005). Its yields depend upon host density and nematode dosage (Boff et al., 2000). In vitro production quality may vary from batch to batch (Cottrell et al., 2011). Whereas in vivo production depends upon the source of production (Gaugler et al., 2000). Now research is being focused on bioreactor design and media optimization, which expected to lead to benefits such as reduced cost and higher yields (Shapiro-Ilan et al., 2014).

\section{Storage}

Entomopathogenic nematodes can be stored in different ways like water-dispersible granules, autoclaved polyether polyurethane foam, alginate gel, vermiculite and baits. EPNs used less energy because they have no fully dormant resting stage, but juveniles can store a little bit of carbohydrate, protein and lipid in them (Andaló et al., 2009). Their quality depends upon the ratio of viable to non-viable, age, virulence and viability assay (Grewal et al., 2005). Low temperatures up to $2-5^{\circ} \mathrm{C}$ can increase shelf life and reduced metabolic activity of nematodes except for $H$. indica and $S$. riobrave which cannot survive below $10^{\circ} \mathrm{C}$ (Grewal, 2002).

\section{Application}

The EPNs can successfully be applied against soil-inhabiting insect pests through soil application and above-ground insects (foliar spray) in cryptic habitats (ShapiroIlan et al., 2006). They can be applied through electrostatic sprayers, mist blowers and pressurized sprayers (Shapiro-Ilan et al., 2006), or by mixing them with water dispersal polymers and particular surfactants (Shapiro-Ilan et al., 2010).

\section{Entomopathogenic nematodes as bio-insecticides}

Chemical insecticides are usually used to control pests of fruits, vegetables and crops in China, their extensive use may cause environmental pollution and hamper the export of products (Jianguang et al., 2008). A high frequency of chemical insecticide application may lead to developing resistance in pests (Feng et al., 2000). Chemical insecticides are carcinogenic and cause environmental pollutions because these are not easily degradable.

Entomopathogenic nematodes are used as insecticides (Ulu et al., 2015). They are eco-friendly and safe for human health. Their associations with bacteria have no harmful impacts on other mammals or plants (Ehlers, 2003). The entomopathogenic nematodes were extensively used as pest control agents in various parts of the world (Kaya et al., 2006; Trdan et al., 2008). As compared with chemical insecticides EPNs are too costly for the average grower in China (Yan et al., 2012). Chemical pesticides may cause problems to EPNs if used arbitrarily (Negrisoli Jr et al., 2010). Entomopathogenic nematodes are utilized as augmentative, classical and conservational biological control agents (Lacey and Georgis, 2012). Entomopathogenic nematodes can effectively control the insect pests listed in Table 1. 
Table 1. Insect-pests controlled by entomopathogenic nematodes

\begin{tabular}{|c|c|c|c|}
\hline Scientific name & Common name & ENP & Reference \\
\hline Agrotis ipsilon & Black cut worm & H. amazonensis & (de Oliviera Giannasi et al., 2018) \\
\hline Alissonotum impressicolle & Banana borer & H. indica & (Anh et al., 2017) \\
\hline Anomala graueri & White grub & S. longicaudum & (Kajuga et al., 2018) \\
\hline Anoplophora glabripennis & Long-horn beetle & S. carpocapsae & (Solter et al., 2001) \\
\hline Arbela dea & Litchi beetle & S. carpocapsae & (Saleh, 2017) \\
\hline Bactrocera tryoni & Queensland fruit fly & H. bacteriophora & (Langford et al., 2014) \\
\hline Bactrocer & Peach fruit fly & H. marelatus & (Saleh et al., 2018) \\
\hline Bradysia odoriphaga & Chive maggot & H. bacteriophora & (Bai et al., 2016) \\
\hline Carposina nipponensis & Apple fruit moth & S. carpocapsae & (Yang et al., 2000) \\
\hline Cephus cinctus & Wheat stem sawfly & S. kraussei & (Portman et al., 2016) \\
\hline Chilo infuscatellus & Sugarcane borer & S. feltiae & (Karunakar et al., 2002) \\
\hline Chironomus plumosus & Buzzer midge & S. kraussei & (Edmunds et al., 2017) \\
\hline Coptotermes formosanus & Termite & S. karii & 2017) \\
\hline Curculio elephas & Chestnut weevil & S. weiseri & (Demir et al., 2015) \\
\hline Cydia pomonella & Codling moth & S. jeffreyense & (Odendaal et al., 2016) \\
\hline Earis vittella & Spotted bollworm & S. mushtaqi & (Pervez and Ali, 2011) \\
\hline Ectomyelois ceratoniae & Carob moth & S. carpocapsae & (Memari et al., 2016) \\
\hline Eriosoma lanigerum & Wooly apple aphid & H. megidis & (Berkvens et al., 2014) \\
\hline Heliothis virescens & Tobacco budworm & H. bacteriophora & (Gulzar et al., 2020) \\
\hline Holcocercus insularis & Tree borer moth & S. carpocapsa & (Kaya et al., 2006) \\
\hline Holotrichia consanguinea & Sugarcane beetle & S. abbasi & (Patil et al., 2016) \\
\hline Holotrichia oblita & White grub & S. longicaudum & (Guo et al., 2015) \\
\hline Holotrichia parallela & Peanut grubs & H. beicherriana & al., 2021) \\
\hline Hylobius abietis & Large pine weevil & S. downesi & (Kapranas et al., 2017) \\
\hline Leucinodes orbonalis & Brinjal fruit borer & S. siamkayai & al., 2010) \\
\hline Maconellicoccus hirsutus & Mango mealybug & H. amazonensis & (Fuenmayor et al., 2020) \\
\hline Macrotermes bellicosus & Termite & H. sonorensis & (Zadji et al., 2014) \\
\hline Mamestra brassicae & Cabbage moth & S. carp & I., 2014) \\
\hline omestica & Housefly & H. in & ., 2018) \\
\hline Mythin & Armyworm & H. indica & (Acharya et al., 2020) \\
\hline ngicollis & Banana borer & S. carp & (Beliel \\
\hline chus ligustici & Alfalfa snout beetle & H. bacteriophora & (Shields et al., 2009) \\
\hline diaphana & Clearwing moth & S. carpocapsae & (Azarnia et al., 2018) \\
\hline Periplaneta & Cockroach & S. carpocapsae & (Maketon et al., 2010) \\
\hline Phyllotreta cruciferae & Crucifer flea beetle & S. carpocapsae & (Reddy et al., 2014) \\
\hline Phyllotreta striolata & Striped flea beetle & S. feltiae & (Xu et al., 2010) \\
\hline Planococcus ficus & Vine mealybug & S. yirgalemense & (Platt et al., 2018) \\
\hline Plutella xylostella & Diamondblack moth & S. carpocapsae & (Sunanda et al., 2014) \\
\hline Polyphylla fullo & Pine chafer & S. glaseri & (Demir et al., 2015) \\
\hline Rhynchophorus ferrugineus & Red palm weevil & S. carpocapsae & (Dembilio et al., 2010) \\
\hline Scirpophaga incertulas & Rice stem borer & H. bacteriophora & (Devi, 2020) \\
\hline Spodoptera littoralis & Cotton leaf worm & S. monticolum & (Sobhy et al., 2020) \\
\hline Spodoptera litura & Armyworm & S. glaseri & (Safdar et al., 2018) \\
\hline Stomoxys calcitrans & Stable fly & H. baujardi & (de Souza Leal et al., 2017) \\
\hline Tuta absoluta & Tomato leaf miner & H. bacteriophora & (Damme et al., 2016) \\
\hline Zeuzera pyrina & Leopard moth & H. bacteriophora & (Salari et al., 2015) \\
\hline
\end{tabular}

Whereas; ENP (entomopathogenic nematodes). List of insect pests currently controlled by applications of entomopathogenic nematodes

\section{Mechanisms of EPNs}

Entomopathogenic nematodes are deadly insect parasites that generate and discharge toxins into their host's body. Main venom proteins include both immune-modulating and tissue-damaging proteins, that these parasites have both a general and a specialized group of effectors, and a modified collection that is more unique to the hosts they invade (Chang et al., 2019). They are used as templates for host-parasite relationships such as host searching behaviour (Lewis et al., 2006), triggering of the parasite (Alonso et al., 2018), 
the function of secreted-products in parasitism (Lu et al., 2017), and ecology (Hodson et al., 2012). Numerous experiments revealed that juveniles of $S$. feltiae use their cuticle to block the immunity of the host (Brivio et al., 2004). Helminthes are commonly known as modulating the host's immune system and inducing pathology primarily by the secretion of small molecules and proteins that interfere with the host's cells (Brivio et al., 2004).

\section{Secretion of lethal venom}

Entomopathogenic nematodes have been widely believed to serve mostly as a vector for pathogenic-bacterial symbiosis. Besides, when these bacteria enter the host, they start to multiply and feed on the tissues of the host, which is responsible for the death of the host (Karthik et al., 2014). There is, however, an increasing body of investigation identifying nematode as a key asset to pathogenesis and in certain instances such as S. scapterisci play the role of the key agent of virulence (Lewis and Clarke, 2012). Apart from acting as a conduit for the bacteria they bring, it is evident that EPNs aid pathogenesis in two different ways such as; they actively destroy the tissue and impede the defense of the host, allowing more energy for themselves and the bacteria they contain to conquer and abolish the host. Previous investigates have revealed that axenic juveniles of $S$. carpocapsae can multiply within the host and destroy the host (Han et al., 2000; Sicard et al., 2003). Specific Steinernematidae effector molecules have been described and shown to participate in tissue damage and immune suppression of host (Toubarro et al., 2013a,b). Chang et al. (2019) revealed that both $S$. carpocapsae and S. feltiae possess a greater concentration of excreted/secreted proteins (ESPs) which are either Ig-like, Von Willebrand, or Ig (immunoglobulin) and FAR (fatty acid/retinol binding-protein). Excreted/secreted proteins (ESPs) are the primary link between hosts and parasites and therefore impact the protection of the parasites and their toxicity of the hosts (CuestaAstroz et al., 2017). However, FAR proteins were believed to influence immune signaling (Kennedy et al., 2013). These secretions of EPNs were found to be a complicated mixture comprising several proteins and together, it is poisonous to insects (Chang et al., 2019).

\section{Nematode defenses and the immune system of insect}

Nematode parasites and their related bacteria are ideal pathogenic agents for antibacterial and anti-nematode immune responses to insect host searches (Kenney and Eleftherianos, 2016). The nematode immune-modulation mechanism demonstrates the variety of modulatory strategies developed for suppression of host immune response by various types of parasitic nematodes (Cooper and Eleftherianos, 2016). In a study, Toubarro et al. (2013b) reported that $S$. carpocapsae displayed destructive approaches for host immunity through proteolytic secretion which inhibits host immunological defenses.

The nematodes and bacteria collaborate to suppress the immune response of the host, allowing vegetative replication of the bacteria (Dowds and Peters, 2002). Xenorhabdus nematophila and $S$. carpocapsae can inhibit the antibacterial peptide immune reaction of insects (Binda-Rossetti et al., 2016). The molecular studies of various insect hosts showed that both Heterorhabditis and Steinernema have a wide variety of results. Such as, Manduca sexta and S. exigua, impedes the transcription genes of insect those encoding for antimicrobial peptides (AMPs); in X. nematophila and S. exigua, cells were capable to impede the development of nodules by inhibiting the biosynthetic pathway of eicosanoid while in P. luminescens and M. sexta, cells released an anti-phagocytic factor that enabled the bacterial cells to disrupt their phagocytosis (Silva et al., 2002; Park et al., 2003, 2007). 
Both bacteria Photorhabdus and Xenorhabdus have also been displayed similar lifestyles but have different molecular defensive mechanisms (Goodrich-Blair and Clarke, 2007). The symbiotic Xenorhabdus bacterium inhibits the host's immune system by producing a variety of toxins and carrying type III effector molecules that may interfere with the actin cytoskeleton and prevent phagocytosis (Dillman et al., 2012a). Photorhabdus used lipopolysaccharide (LPS) modification to resist the action of the hostderived AMPs (Eleftherianos et al., 2006), while Xenorhabdus prevents induction of insect AMP expression altogether (Istkhar et al., 2019). In insects, the pathogenic impacts of bacteria and the anti-bacterial resistance mechanisms have been well described, however, nematode-associated defenses are nowadays primarily the focus of research. The EPN-pest interaction is illustrated in Fig. 1.

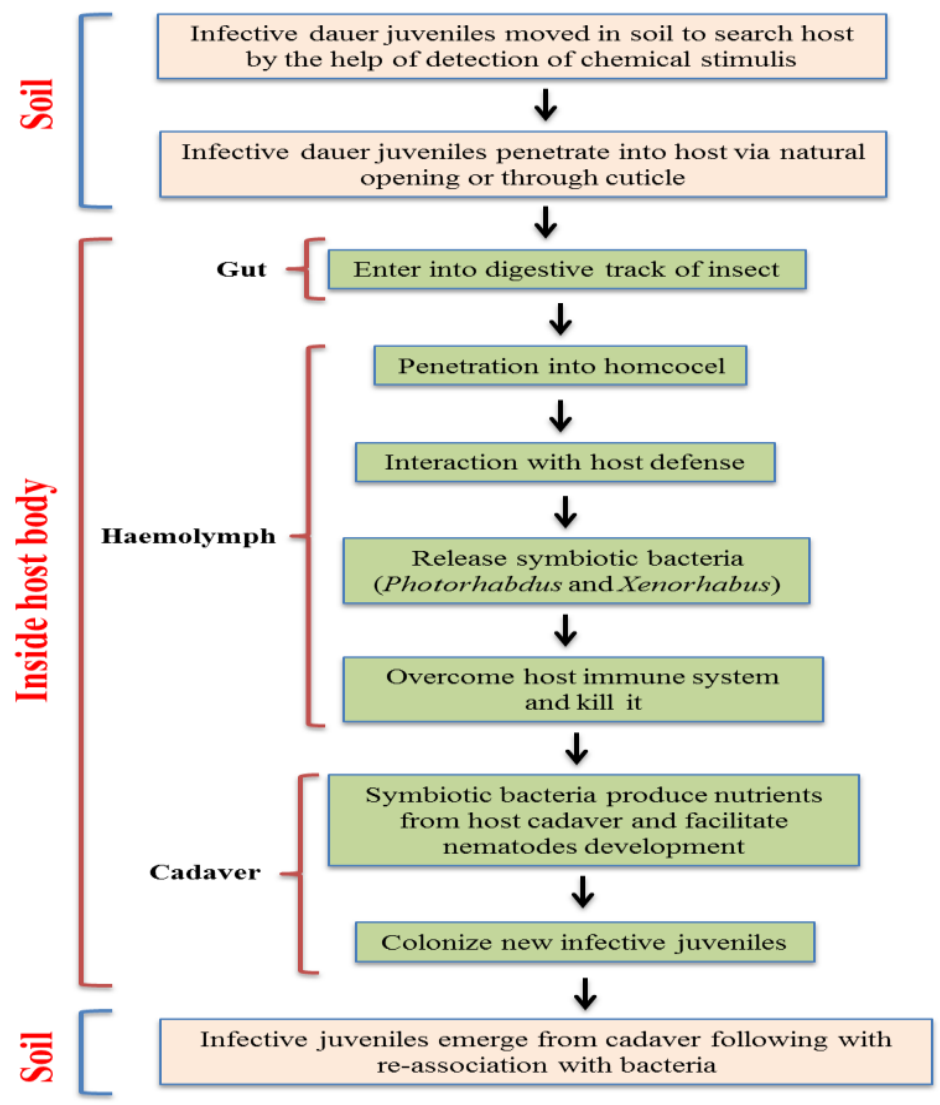

Figure 2. The interaction between entomopathogenic nematodes and pests

\section{Commercially available entomopathogenic nematodes worldwide}

In recent years, Heterorhabditis and Steinernema products have successfully been manufactured and commercialized by various companies around the world. The most popular species that have been successfully manufactured and utilized as commercial products are $H$. bacteriophora, $H$. downesi, $H$. indica, H. megidis, S. carpocapsae, S. feltiae, S. kraussei, S. kushidai, S. riobrave and S. scapterisci (Table 2). The EPN products are marketed under various brands, in developed and developing countries of the world, such as Austria, Australia, Belgium, Canada, Germany, India, Japan, Kenya, Lietuva, Netherlands, Newzealand, Poland, the United Kingdom and the United State of America. 
Table 2. Commercial products of entomopathogenic nematodes (EPNs) prepared by different countries

\begin{tabular}{|c|c|c|}
\hline EPN & Commercial product & Manufacturer \\
\hline H. bacteriophora & $\begin{array}{l}\text { Larvanem } \\
\text { NemaShield-HB } \\
\text { Nematop } \\
\text { NemaTrident-C } \\
\text { Nema-green } \\
\text { Otinem } \\
\text { Optinem-H } \\
\text { E-Nema Gmbh }\end{array}$ & $\begin{array}{c}\text { Koppert Biological System, Berkel en Rodenrijs, NL } \\
\text { BioWorks Inc. Victor, New York State, US } \\
\text { BioForce Limited, Drury, NZL } \\
\text { Bionema Limited, Swansea, UK } \\
\text { e-nema, Schwentinental, Germany } \\
\text { Bioenterprises PTY Limited, Roseville, NSW } \\
\text { Agronovos, Ąžuolo g. 25, Alionių II k, Lietuva } \\
\text { e-nema, Schwentinental, Germany }\end{array}$ \\
\hline H. downesi & NemaTrident-CT & Bionema Limited, Swansea, UK \\
\hline H. indica & $\begin{array}{c}\text { Calterm } \\
\text { Grub Terminator } \\
\text { GrubStake-Hi } \\
\text { Soldier } \\
\end{array}$ & $\begin{array}{c}\text { Kisan Manch, IN } \\
\text { Benzer Crop Science, Sirsi, IN } \\
\text { Integrated Biocontrol System Inc., Greendale IN } \\
\text { Swami Samarth Agro Biotech LLP, Pune, IN }\end{array}$ \\
\hline H. megidis & $\begin{array}{l}\text { LarvaNema } \\
\text { Nemasys H }\end{array}$ & $\begin{array}{c}\text { Koppert B.V., Berkel en Rodenngs, NL } \\
\text { MicroBto, Cambndge, UK }\end{array}$ \\
\hline S. carpocapsae & $\begin{array}{c}\text { BioSafe } \\
\text { Biosafe-N } \\
\text { BioVector } \\
\text { Bouncer } \\
\text { Boden-Niitzlinge } \\
\text { Capsanem } \\
\text { Carpocapsae-System } \\
\text { Exhibitline SC } \\
\text { Helix } \\
\text { Optinem-C } \\
\text { Mioplant } \\
\text { NemaGard } \\
\text { Nemastar } \\
\text { NemaTrident-T } \\
\text { Nemasys C } \\
\text { Palma-Life } \\
\text { Vector TL } \\
\text { X-GNAT }\end{array}$ & $\begin{array}{c}\text { SDS Biotech, Minato-Ku, Tokyo, Japan } \\
\text { Thermo Triology, Corp., Columbia, MD } \\
\text { Thermo Triology, Corp., Columbia, MD } \\
\text { Swami Samarth Agro Biotech LLP, Pune, IN } \\
\text { Rhone-Poulenc, Celaflor, Germany } \\
\text { Koppert Biological System, Berkel en Rodenrijs, NL } \\
\text { Biobest Sustainable Crop Management, Westerlo, BEL } \\
\text { Bioline AgroSciences Ltd. Camarillo, US } \\
\text { Novartts, Misnssauga, Canada } \\
\text { Agronovos, Ažzuolo g. 25, Alionių II k, Lietuva } \\
\text { Novartts, Vienna, Austria } \\
\text { Purely Organic Products LLC, Portsmouth, US } \\
\text { BioForce Limited, Drury, NZL } \\
\text { Bionema Limited, Swansea, UK } \\
\text { BASF Corporation, Ludwigshafen, Germany } \\
\text { Biobest Sustainable Crop Management, Westerlo, BEL } \\
\text { Lesco, Lansing, MI } \\
\text { E C Geiger, Harleysvtlle, PA }\end{array}$ \\
\hline S. feltiae & $\begin{array}{l}\text { Entonem } \\
\text { Exhibit } \\
\text { Magnat } \\
\text { Nemasys } \\
\text { NemaShield } \\
\text { NemaTrident-F } \\
\text { Nemapom } \\
\text { Nemaplus } \\
\text { Nemaflor } \\
\text { Nemasys F } \\
\text { Nematech-S SP } \\
\text { NemaTrident-S } \\
\text { Nemax-F } \\
\text { Nemycel } \\
\text { Optinem-F } \\
\text { Owinema SC } \\
\text { Stealth } \\
\end{array}$ & $\begin{array}{c}\text { Koppert Biological System, Berkel en Rodenrijs, NL } \\
\text { Novartts, Basel, Switzerland } \\
\text { Amycel-Spawn Mate, Watsonvllle, CA } \\
\text { MicroBto, Cambndge, UK } \\
\text { BioWorks Inc. Victor, New York State, US } \\
\text { Bionema Limited, Swansea, UK } \\
\text { e-nema, Schwentinental, Germany } \\
\text { BioForce Limited, Drury, NZL } \\
\text { e-nema, Schwentinental, Germany } \\
\text { BASF Corporation, Ludwigshafen, Germany } \\
\text { Dudutech, Naivasha, Kenya } \\
\text { Bionema Limited, Swansea, UK } \\
\text { Serbios, Badia Polesine, Italy } \\
\text { e-nema, Schwentinental, Germany } \\
\text { Agronovos, Azžuolo g. 25, Alionių II k, Lietuva } \\
\text { Owiplant Ltd. Horticultural Enterprise, Poznań, PL } \\
\text { Novartis, Macclesfield, Chester, UK } \\
\end{array}$ \\
\hline S. kraussei & Exhibitline Sk & Bioline AgroSciences Ltd. Camarillo, US \\
\hline S. kushidai & $\begin{array}{c}\text { SDS biotech } \\
\text { Kraussei-System }\end{array}$ & $\begin{array}{c}\text { SDS Biotech K.K, Tsukuba, Japan } \\
\text { Biobest Sustainable Crop Management, Westerlo, BEL }\end{array}$ \\
\hline S. riobrave & $\begin{array}{l}\text { Biovector } \\
\text { Vector MC }\end{array}$ & $\begin{array}{l}\text { Thermo Triology, Corp., Columbia, MD } \\
\text { Lesco, Lansing, MI }\end{array}$ \\
\hline S. scapterisci & Proactant Ss & BtoControl, Gamesvtlle, FL \\
\hline
\end{tabular}

The representative trade names are those displayed on the respective company websites 


\section{Conclusion}

In the end, it is concluded that EPNs are suggested to be used as biopesticides due to huge host range, safety and compatibility within a variety of environmental conditions. Entomopathogenic nematodes are excellent biological control agents for soil-dwelling insects. Its mutual association with bacteria can easily kill insect pests so that they can be applied easily. Better understanding and development of EPNs are necessary for a suitable replacement of synthetic pesticides. More research is needed in China and all over the world to evaluate the biopesticides potential of EPNs as an effective tool for integrated pest management (IPM). Nowadays, the immune system of insects is being studied on a wide scale but their associations with EPNs are still less studied. The analysis of insect defenses and EPNs offenses would give a more precise description for effective control of insect pests as a future prospect. A better understanding of insect defense mechanisms against the EPNs and decreasing them by some adjuvants or nematode species with complex pathogenicity and powerful immune-suppressive abilities may be useful for potential pest management programs in the future.

Acknowledgements. The financial support was provided by the National Nature Science Fund Key Projects (313300630), China Agriculture Research System CARS-04-PS13 and National Parasitic Resources Center (NPRC-2019-194-30).

Conflict of interests. Authors have no conflict of interests.

\section{REFERENCES}

[1] Abate, B. A., Wingfield, M. J., Slippers, B., Hurley, B. P. (2017): Commercialisation of entomopathogenic nematodes: should import regulations be revised? - Biocontrol Science and Technology 27: 149-168.

[2] Acharya, R., Hwang, H.-S., Mostafiz, M. M., Yu, Y.-S., Lee, K.-Y. (2020): Susceptibility of Various Developmental Stages of the Fall Armyworm, Spodoptera frugiperda, to Entomopathogenic Nematodes. - Insects 11: 868.

[3] Adams, B. J., Nguyen, K. B. (2002): Taxonomy and systematics. - In: Gaugler, A. (ed.) Entomopathogenic nematology. CABI, Wallingford, UK.

[4] Adiroubane, D., Tamilselvi, R., Ramesh, V. (2010): Efficacy of Steinernema siamkayai against certain crop pests. - Journal of Biopesticides 3: 180-185.

[5] Akhurst, R., Smith, K. (2002): Regulation and Safety. - In: Gaugler, R. (ed.) Entomopathogenic nematology. CABI, Wallingford, UK.

[6] Alonso, V., Nasrolahi, S., Dillman, A. R. (2018): Host-specific activation of entomopathogenic nematode infective juveniles. - Insects 9: 59.

[7] Anbesse, S., Sumaya, N. H., Dörfler, A. V., Strauch, O., Ehlers, R.-U. (2013): Selective breeding for desiccation tolerance in liquid culture provides genetically stable inbred lines of the entomopathogenic nematode Heterorhabditis bacteriophora. - Applied microbiology and biotechnology 97: 731-739.

[8] Andaló, V., Moreira, G., Maximiniano, C., Moino, A., Campos, V. (2009): Influence of herbicides on lipid reserves, mortality and infectivity of Heterorhabditis amazonensis (Rhabditida: Heterorhabditidae). - Nematologia Mediterranea 37: 11-15.

[9] Andaló, V., Moreira, G. F., Moino Junior, A. (2017): Host-seeking behavior of the Heterorhabditis amazonensis nematode in response to stimulant sources. - Pesquisa Agropecuária Tropical 47: 265-272. 
[10] Anh, Đ. T., Tiền, N. H., Châu, N. N. (2017): The pathogenicity and reproduction capability of five epn strains on white grubs (Alissonotum impressicolle Arrow) in the laboratory conditions. - Vietnam Journal of Biotechnology 15: 277-284.

[11] Askary, T. H., Ahmad, M. J., Wani, A., Mohiddin, S., Sofi, M. A. (2018): Behavioural Ecology of Entomopathogenic Nematodes, Steinernema and Heterorhabditis for Insect Biocontrol. - Sustainable Agriculture Reviews 31: 425-441.

[12] Azarnia, S., Abbasipour, H., Saeedizadeh, A., Askarianzadeh, A. (2018): Laboratory Assay of Entomopathogenic Nematodes Against Clearwing Moth (Lepidoptera: Sesiidae) Larvae. - Journal of Entomological Science 53: 62-69.

[13] Bai, G.-Y., Xu, H., Fu, Y.-Q., Wang, X.-Y., Shen, G.-S., Ma, H.-K., Feng, X., Pan, J., Gu, X.-S., Guo, Y.-Z. (2016): A comparison of novel entomopathogenic nematode application methods for control of the chive gnat, Bradysia odoriphaga (Diptera: Sciaridae). - Journal of Economic Entomology 109: 2006-2013.

[14] Bal, H. K., Grewal, P. S. (2017): Entomopathogenic Nematodes for Management of Insect Pests of Canola and Other Oilseed Crops. - In: Reddy, G. V. P. (ed.) Integrated Management of Insect Pests on Canola and Other Brassica Oilseed Crops. CABI, Wallingford, UK.

[15] Banu, J. G. (2017): Efficacy of Entomopathogenic Nematodes Against Coleopteran Pests. - In: Abd-Elgawad, M. M. M., Askary, T. H., Coupland, J. (eds.) Biocontrol Agents: Entomopathogenic and Slug Parasitic Nematodes. CABI, Wallingford, UK.

[16] Beck, B., Brusselman, E., Nuyttens, D., Moens, M., Temmerman, F., Pollet, S., Van Weyenberg, S., Spanoghe, P. (2014): Improving the biocontrol potential of entomopathogenic nematodes against Mamestra brassicae: effect of spray application technique, adjuvants and an attractant. - Pest Management Science 70: 103-112.

[17] Belien, T. (2018): Entomopathogenic nematodes as biocontrol agents of insect pests in orchards. - CAB Reviews 13: 1-11.

[18] Berkvens, N., Van Vaerenbergh, J., Maes, M., Beliën, T., Viaene, N. (2014): Entomopathogenic nematodes fail to parasitize the woolly apple aphid Eriosoma lanigerum as their symbiotic bacteria are suppressed. - Journal of Applied Entomology 138: 644-655.

[19] Binda-Rossetti, S., Mastore, M., Protasoni, M., Brivio, M. F. (2016): Effects of an entomopathogen nematode on the immune response of the insect pest red palm weevil: Focus on the host antimicrobial response. - Journal of Invertebrate Pathology 133: 110119.

[20] Boff, M. I., Wiegers, G. L., Gerritsen, L. J., Smits, P. H. (2000): Development of the entomopathogenic nematode Heterorhabditis megidis strain NLH-E 87.3 in Galleria mellonella. - Nematology 2: 303-308.

[21] Bream, A., Fouda, M. A., Shehata, I., Ragab, S. (2018): Evaluation of Four Entomopathogenic Nematodes as Biological Control Agents Against the Housefly, Musca domestica L. (Diptera: Muscidae). - Egyptian Academic Journal of Biological Sciences A Entomology 11(1): 79-89.

[22] Brivio, M. F., Mastore, M., Moro, M. (2004): The role of Steinernema feltiae bodysurface lipids in host-parasite immunological interactions. - Molecular and Biochemical Parasitology 135: 111-121.

[23] Chang, D. Z., Serra, L., Lu, D., Mortazavi, A., Dillman, A. R. (2019): A core set of venom proteins is released by entomopathogenic nematodes in the genus Steinernema. PLoS Pathogens 15: e1007626.

[24] Chavarría-Hernández, N., Ortega-Morales, E., Vargas-Torres, A., Chavarría-Hernández, J.-C., Rodríguez-Hernández, A.-I. (2010): Submerged monoxenic culture of the entomopathogenic nematode, Steinernema carpocapsae CABA01, in a mechanically agitated bioreactor: Evolution of the hydrodynamic and mass transfer conditions. Biotechnology and Bioprocess Engineering 15: 580-589. 
[25] Chunjie, L., Guozhong, T., Yi, W. (2011): Occurrence of entomopathogenic nematodes resources and overwintering conditions in Heilongjiang Province. - Plant Protection 37: 120-123.

[26] Cooper, D., Eleftherianos, I. (2016): Parasitic nematode immunomodulatory strategies: recent advances and perspectives. - Pathogens 5: 58.

[27] Cottrell, T., Shapiro-Ilan, D., Horton, D., Mizell III, R. (2011): Laboratory virulence and orchard efficacy of entomopathogenic nematodes against the lesser peachtree borer (Lepidoptera: Sesiidae). - Journal of economic entomology 104: 47-53.

[28] Cuesta-Astroz, Y., de Oliveira, F. S., Nahum, L. A., Oliveira, G. (2017): Helminth secretomes reflect different lifestyles and parasitized hosts. - International Journal for Parasitology 47: 529-544.

[29] Damme, V. M. V., Beck, B. K., Berckmoes, E., Moerkens, R., Wittemans, L., De Vis, R., Nuyttens, D., Casteels, H. F., Maes, M., Tirry, L. (2016): Efficacy of entomopathogenic nematodes against larvae of Tuta absoluta in the laboratory. - Pest Management Science 72: 1702-1709.

[30] Davari, A., Parker, B. L. (2018): A review of research on Sunn Pest \{Eurygaster integriceps Puton (Hemiptera: Scutelleridae)\} management published 2004-2016. Journal of Asia-Pacific Entomology 21: 352-360.

[31] De Brida, A. L., Rosa, J. M. O., De Oliveira, C. M. G., de Castro e Castro, B. M., Serrão, J. E., Zanuncio, J. C., Leite, L. G., Wilcken, S. R. S. (2017): Entomopathogenic nematodes in agricultural areas in Brazil. - Scientific Reports 7: 45254.

[32] De Oliviera Giannasi, A., Roque Brambila, C., Zart, M., Guide, B. A., Alves, V. S. (2018): Assessment of entomopathogenic nematodes in Agrotis ipsilon (Lepidoptera: Noctuidae) under laboratory and greenhouse conditions. - Revista Colombiana de Entomología 44(1): 25-31.

[33] De Siqueira Sabino, P., Sales, F. S., Guevara, E. J., Moino, J., Filgueiras, C. C. (2014): Compatibility of entomopathogenic nematodes (Nematoda: Rhabditida) with insecticides used in the tomato crop. - Nematoda 1: eo2014.

[34] De Souza Rodrigues Leal, L. C., de Oliviera Monteiro, C. M., de Mendonça, A. É., Bittencourt, V. R. E. P., Bittencourt, A. J. (2017): Potential of entomopathogenic nematodes of the genus Heterorhabditis for the control of Stomoxys calcitrans (Diptera: Muscidae). - Revista Brasileira de Parasitologia Veterinária 26(4): 451-456.

[35] Del Pino, F. G., Morton, A., Shapiro-Ilan, D. (2018): Entomopathogenic Nematodes as Biological Control Agents of Tomato Pests. - In: Wakil, W., Brust, G. E., Perring, T. M. (eds.) Sustainable Management of Arthropod Pests of Tomato. Elsevier.

[36] Dembilio, O., Llácer, E., Martínez de Altube, M. d. M., Jacas, J. A. (2010): Field efficacy of imidacloprid and Steinernema carpocapsae in a chitosan formulation against the red palm weevil Rhynchophorus ferrugineus (Coleoptera: Curculionidae) in Phoenix canariensis. - Pest Management Science: Formerly Pesticide Science 66: 365-370.

[37] Demir, S., Karagoz, M., Hazir, S., Kaya, H. K. (2015): Evaluation of entomopathogenic nematodes and their combined application against Curculio elephas and Polyphylla fullo larvae. - Journal of Pest Science 88: 163-170.

[38] Devi, G. (2020): Entomopathogenic Nematodes against Insect Pests of Rice. International Journal of Environment, Agriculture and Biotechnology 5: 1143-1150.

[39] Dillman, A. R., Chaston, J. M., Adams, B. J., Ciche, T. A., Goodrich-Blair, H., Stock, S. P., Sternberg, P. W. (2012a): An entomopathogenic nematode by any other name. - PLoS Pathogens 8: e1002527.

[40] Dillman, A. R., Guillermin, M. L., Lee, J. H., Kim, B., Sternberg, P. W., Hallem, E. A. (2012b): Olfaction shapes host-parasite interactions in parasitic nematodes. Proceedings of the National Academy of Sciences 109: E2324-E2333.

[41] Dillman, A. R. (2013): Host seeking and the genomic architecture of parasitism among entomopathogenic nematodes. - California Institute of Technology. 
[42] Divya, K., Sankar, M. (2009): Entomopathogenic nematodes in pest management. Indian Journal of Science and Technology 2: 53-60.

[43] Dowds, B. C., Peters, A. (2002): Virulence mechanisms. - In: Gaugler, R. (ed.) Entomopathogenic nematology. CABI, New York.

[44] Dutka, A., McNulty, A., Williamson, S. M. (2015): A new threat to bees? Entomopathogenic nematodes used in biological pest control cause rapid mortality in Bombus terrestris. - PeerJ 3: e1413.

[45] Edmunds, C., Rae, R., Edmunds, S., Wilding, C. (2017): Susceptibility of Chironomus plumosus larvae (Diptera: Chironomidae) to entomopathogenic nematodes (Rhabditida: Steinernematidae and Heterorhabditidae): Potential for control. - European Journal of Entomology 114: 526-532.

[46] Ehlers, R. (2003): Entomopathogenic nematodes in the European biocontrol market. Communications in agricultural and applied biological sciences 68: 3-16.

[47] Ehlers, R.-U., Shapiro-Ilan, D. I. (2005): Mass production. - In: Grewal, P. S., Ehlers, R.U., Shapiro-Ilan, D. I. (eds.) Nematodes as biocontrol agents. CABI, Wallingford, UK.

[48] Eleftherianos, I., Millichap, P. J., Reynolds, S. E. (2006): RNAi suppression of recognition protein mediated immune responses in the tobacco hornworm Manduca sexta causes increased susceptibility to the insect pathogen Photorhabdus. - Developmental and Comparative Immunology 30: 1099-1107.

[49] Feng, H., Huang, Y., Hsu, J. (2000): Insecticide susceptibility of cabbage flea beetle (Phyllotreta striolata (Fab.)) in Taiwan. - Plant Protection Bulletin (Taipei) 42: 67-72.

[50] Ferreira, T., Malan, A. (2014): Xenorhabdus and Photorhabdus, bacterial symbionts of the entomopathogenic nematodes Steinernema and Heterorhabditis and their in vitro liquid mass culture: a review. - African Entomology 22: 1-14.

[51] Ferris, H., Griffiths, B. S., Porazinska, D. L., Powers, T. O., Wang, K. H., Tenuta, M. (2012): Reflections on Plant and Soil Nematode Ecology: Past, Present and Future. Journal of Nematology 44: 115-126.

[52] Fuchs, A. (1915): Die Naturgeschichte der Nematoden und einiger anderen Parasiten. 1. Des Ips typographus L. 2. Des Hylobius abietis L. Zool. Jahrb., Abt. Syst. - Okol. Geogr. Tiere 38: 109-222.

[53] Fuenmayor, Y., Portillo, E., Bastidas, B., Guerra, M., San-Blas, E. (2020): Infection parameters of Heterorhabditis amazonensis (Nematoda: Heterorhabditidae) in different stages of Hibiscus pink mealybug. - Journal of Nematology 52: e2020-77.

[54] Fujimoto, A., Lewis, E., Cobanoglu, G., Kaya, H. K. (2007): Dispersal, infectivity and sex ratio of early-or late-emerging infective juveniles of the entomopathogenic nematode Steinernema carpocapsae. - Journal of Nematology 39: 333-337.

[55] Gaugler, R., Grewal, P., Kaya, H. K., Smith-Fiola, D. (2000): Quality assessment of commercially produced entomopathogenic nematodes. - Biological Control 17: 100-109.

[56] Goodrich-Blair, H., Clarke, D. J. (2007): Mutualism and pathogenesis in Xenorhabdus and Photorhabdus: two roads to the same destination. - Molecular Microbiology 64: 260268.

[57] Grewal, P. S. (2002): Formulation and Application Technology. - In: Gaugler, R. (ed.) Entomopathogenic nematology. CABI, Wallingford, UK.

[58] Grewal, P. S., Ehlers, R. U., Shapiroilan, D. I. (2005): Nematodes as biocontrol agents. CABI, New York.

[59] Griffin, C., Chaerani, R., Fallon, D., Reid, A., Downes, M. (2000): Occurrence and distribution of the entomopathogenic nematodes Steinernema spp. and Heterorhabditis indica in Indonesia. - Journal of Helminthology 74: 143-150.

[60] Gulzar, A., Mukhtar, T., Wright, D. J. (2020): Effects of entomopathogenic nematodes Steinernema carpocapsae and Heterorhabditis bacteriophora on the fitness of a Vip3A resistant subpopulation of Heliothis virescens (Noctuidae: Lepidoptera). - Bragantia 79: 281-292. 
[61] Guo, W., Yan, X., Zhao, G., Chen, J., Han, R. (2015): Efficacy of entomopathogenic Steinernema and Heterorhabditis nematodes against Holotrichia oblita. - Journal of Pest Science 88: 359-368.

[62] Han, R., Cao, L., He, X. Y., Li, Q. J., Liu, X. L., Huang, H., Pang, Y., He, M. (2000): Recovery response of Heterorhabditis bacteriophora and Steinernema carpocapsae to different non-symbiotic microorganisms. - Insect Science 7: 271-277.

[63] Hirao, A., Ehlers, R.-U. (2010): Influence of inoculum density on population dynamics and dauer juvenile yields in liquid culture of biocontrol nematodes Steinernema carpocapsae and S. feltiae (Nematoda: Rhabditida). - Applied microbiology and biotechnology 85: 507-515.

[64] Hoctor, T. L., Gibb, T. J., Bigelow, C. A., Richmond, D. S. (2012): Survival and Infectivity of the Insect-Parasitic Nematode Heterorhabditis bacteriophora Poinar in Solutions Containing Four Different Turfgrass Soil Surfactants. - Insects 4: 1-8.

[65] Hodson, A., Siegel, J., Lewis, E. (2012): Ecological influence of the entomopathogenic nematode, Steinernema carpocapsae, on pistachio orchard soil arthropods. Pedobiologia 55: 51-58.

[66] Hussaini, S. S. (2017): Entomopathogenic nematodes: Ecology, diversity and geographical distribution. - In: Abd-Elgawad, M. M., Askary, T. H., Coupland, J. (eds.) Biocontrol Agents: Entomopathogenic and Slug Parasitic Nematodes. CABI, Wallingford, UK.

[67] Istkhar, R., Chaubey, A. K., Garg, A. P. (2019): Entomopathogenic Nematodes in the Biological Control of Insect Pests with Reference to Insect Immunity. - In: Varma, A., Tripathi, S., Prasad, R. (eds.) Plant Biotic Interactions. Springer, Switzerland AG.

[68] Jagdale, G. B., Grewal, P. S., Salminen, S. O. (2005): Both heat-shock and cold-shock influence trehalose metabolism in an entomopathogenic nematode. - Journal of Parasitology 91: 988-994.

[69] Jianguang, S., Ruibo, J., Tianzhi, R., Ligang, W., Jing, X. (2008): Prospect for farmland and water pollution and microorganism repair in China. - Chinese Journal of Agricultural Resources and Regional Planning 29: 41-47.

[70] Kajuga, J., Hategekimana, A., Yan, X., Waweru, B. W., Li, H., Li, K., Yin, J., Cao, L., Karanja, D., Umulisa, C. (2018): Management of white grubs (Coleoptera: Scarabeidae) with entomopathogenic nematodes in Rwanda. - Egyptian Journal of Biological Pest Control 28: 1-13.

[71] Kapranas, A., Malone, B., Quinn, S., Mc Namara, L., Williams, C. D., O'Tuama, P., Peters, A., Griffin, C. T. (2017): Efficacy of entomopathogenic nematodes for control of large pine weevil, Hylobius abietis: effects of soil type, pest density and spatial distribution. - Journal of Pest Science 90: 495-505.

[72] Karthik, L., Kumar, G., Keswani, T., Bhattacharyya, A., Chandar, S. S., Rao, K. B. (2014): Protease inhibitors from marine actinobacteria as a potential source for antimalarial compound. - PloS One 9: e90972.

[73] Karunakar, G., Easwaramoorthy, S., David, H. (2002): Interaction between entomopathogenic nematodes and granulosis viruses of Chilo infuscatellus Snellen and Chilo sacchariphagus indicus (Kapur). - Journal of Biological Control 16: 153-156.

[74] Kaya, H. K., Aguillera, M., Alumai, A., Choo, H. Y., De la Torre, M., Fodor, A., Ganguly, S., Hazır, S., Lakatos, T., Pye, A. (2006): Status of entomopathogenic nematodes and their symbiotic bacteria from selected countries or regions of the world. Biological control 38: 134-155.

[75] Kennedy, M. W., Corsico, B., Cooper, A., Smith, B. O. (2013): The Unusual Lipidbinding Proteins of Nematodes: NPAs, nemFABPs and FARs. - In: Kennedy, M., Harnett, W. (eds.) Parasitic nematodes: molecular biology, biochemistry and immunology. CABI, Wallingford, UK.

[76] Kenney, E., Eleftherianos, I. (2016): Entomopathogenic and plant pathogenic nematodes as opposing forces in agriculture. - International Journal for Parasitology 46: 13-19. 
[77] Kergunteuil, A., Bakhtiari, M., Formenti, L., Xiao, Z., Defossez, E., Rasmann, S. (2016): Biological control beneath the feet: a review of crop protection against insect root herbivores. - Insects 7: 70.

[78] Lacey, L. A., Georgis, R. (2012): Entomopathogenic nematodes for control of insect pests above and below ground with comments on commercial production. - Journal of Nematology 44: 218-225.

[79] Lacey, L., Grzywacz, D., Shapiro-Ilan, D., Frutos, R., Brownbridge, M., Goettel, M. (2015): Insect pathogens as biological control agents: back to the future. - Journal of Invertebrate Pathology 132: 1-41.

[80] Langford, E. A., Nielsen, U. N., Johnson, S. N., Riegler, M. (2014): Susceptibility of Queensland fruit fly, Bactrocera tryoni (Froggatt) (Diptera: Tephritidae), to entomopathogenic nematodes. - Biological Control 69: 34-39.

[81] Laznik, Ž., Tóth, T., Lakatos, T., Vidrih, M., Trdan, S. (2010): Control of the Colorado potato beetle (Leptinotarsa decemlineata [Say]) on potato under field conditions: a comparison of the efficacy of foliar application of two strains of Steinernema feltiae (Filipjev) and spraying with thiametoxam. - Journal of Plant Diseases and Protection 117: 129-135.

[82] Laznik, Z., Znidarcic, D., Trdan, S. (2011): Control of Trialeurodes vaporariorum (Westwood) adults on glasshouse-grown cucumbers in four different growth substrates: an efficacy comparison of foliar application of Steinernema feltiae (Filipjev) and spraying with thiamethoxamn. - Turkish Journal of Agriculture and Forestry 35: 631-640.

[83] Laznik, Ž., Trdan, S. (2014): The influence of insecticides on the viability of entomopathogenic nematodes (Rhabditida: Steinernematidae and Heterorhabditidae) under laboratory conditions. - Pest management science 70: 784-789.

[84] Lewis, E. E., Campbell, J., Griffin, C., Kaya, H., Peters, A. (2006): Behavioral ecology of entomopathogenic nematodes. - Biological Control 38: 66-79.

[85] Lewis, E. E., Clarke, D. J. (2012): Nematode parasites and entomopathogens. - In: Vega, F. E., Kaya, H. K. (eds.) Insect Pathology (Second Edition). Elsevier, Amsterdam.

[86] Li, E.-T., Zhang, S., Li, K.-B., Nyamwasaa, I., Li, J.-Q., Li, X.-F., Qin, J.-H., Yin, J. (2021): Efficacy of entomopathogenic nematode and Bacillus thuringiensis combinations against Holotrichia parallela (Coleoptera: Scarabaeidae) larvae. - Biological Control 152: 104469.

[87] Lortkipanidze, M. A., Gorgadze, O. A., Kajaia, G. S., Gratiashvili, N. G., Kuchava, M. A. (2016): Foraging behavior and virulence of some entomopathogenic nematodes. - Annals of Agrarian Science 14: 99-103.

[88] Lu, D., Macchietto, M., Chang, D., Barros, M. M., Baldwin, J., Mortazavi, A., Dillman, A. R. (2017): Activated entomopathogenic nematode infective juveniles release lethal venom proteins. - PLoS Pathogens 13: e1006302.

[89] Ma, J., Chen, S., Zou, Y., Li, X., Han, R., De Clercq, P., Moens, M. (2010): Natural occurrence of entomopathogenic nematodes in North China. - Russian Journal of Nematology 18: 117.

[90] Mahmoud, M. (2016): Biology and Use of Entomopathogenic Nematodes in Insect Pests Biocontrol, A Generic View. - Cercetari Agronomice in Moldova 49: 85-105.

[91] Maketon, M., Hominchan, A., Hotaka, D. (2010): Control of American cockroach (Periplaneta americana) and German cockroach (Blattella germanica) by entomopathogenic nematodes. - Revista Colombiana de Entomología 36: 249-253.

[92] Memari, Z., Karimi, J., Kamali, S., Goldansaz, S. H., Hosseini, M. (2016): Are entomopathogenic nematodes effective biological control agents against the carob moth, Ectomyelois ceratoniae? - Journal of Nematology 48: 261-267.

[93] Mohan, S. (2015): Entomopathogenic Nematodes and Their Bacterial Symbionts as Lethal Bioagents of Lepidopteran Pests. - In: Sree, K. S., Varma, A. (eds.) Biocontrol of Lepidopteran Pests. Springer, Switzerland. 
[94] Negrisoli Jr, A. S., Garcia, M. S., Negrisoli, C. R. B. (2010): Compatibility of entomopathogenic nematodes (Nematoda: Rhabditida) with registered insecticides for Spodoptera frugiperda (Smith, 1797) (Lepidoptera: Noctuidae) under laboratory conditions. - Crop Protection 29: 545-549.

[95] Noosidum, A., Hodson, A. K., Lewis, E. E., Chandrapatya, A. (2010): Characterization of new entomopathogenic nematodes from Thailand: foraging behavior and virulence to the greater wax moth, Galleria mellonella L. (Lepidoptera: Pyralidae). - Journal of Nematology 42: 281-291.

[96] Odendaal, D., Addison, M. F., Malan, A. P. (2016): Control of diapausing codling moth, Cydia pomonella (Lepidoptera: Tortricidae) in wooden fruit bins, using entomopathogenic nematodes (Heterorhabditidae and Steinernematidae). - Biocontrol Science and Technology 26: 1504-1515.

[97] Onstad, D., Fuxa, J., Humber, R., Oestergaard, J., Shapiro-Ilan, D., Gouli, V., Anderson, R., Andreadis, T., Lacey, L. (2006): An abridged glossary of terms used in invertebrate pathology. - Society for Invertebrate Pathology.

[98] Park, Y., Kim, Y., Putnam, S. M., Stanley, D. W. (2003): The bacterium Xenorhabdus nematophilus depresses nodulation reactions to infection by inhibiting eicosanoid biosynthesis in tobacco hornworms, Manduca sexta. - Archives of Insect Biochemistry and Physiology: Published in Collaboration with the Entomological Society of America 52: 71-80.

[99] Park, Y., Herbert, E. E., Cowles, C. E., Cowles, K. N., Menard, M. L., Orchard, S. S., Goodrich-Blair, H. (2007): Clonal variation in Xenorhabdus nematophila virulence and suppression of Manduca sexta immunity. - Cellular Microbiology 9: 645-656.

[100] Patil, J., Rangasamy, V., Verghese, A. (2016): Efficacy of indigenous Steinernema abbasi and Heterorhabditis indica isolates as potential biocontrol agent against Holotrichia consanguinea Blanch. (Coleoptera: Scarabaeidae). - Nematology 18: 10451052.

[101] Pervez, R., Ali, S. (2011): Infectivity of Steinernema mushtaqi (Rhabditida: Steinernematidae) against insect pests and their mass production. - Archives of Phytopathology and Plant Protection 44: 1352-1355.

[102] Platt, T., Stokwe, N., Malan, A. P. (2018): Potential of local entomopathogenic nematodes for control of the vine mealybug, Planococcus ficus. - South African Journal of Enology and Viticulture 39: 1-8.

[103] Portman, S. L., Krishnankutty, S. M., Reddy, G. V. (2016): Entomopathogenic nematodes combined with adjuvants presents a new potential biological control method for managing the wheat stem sawfly, Cephus cinctus (Hymenoptera: Cephidae). - PloS One 11: e0169022.

[104] Radová, Š. (2010): Can pre-colonisation of the soil substrate increase the efficacy of entomopathogenic nematodes (Rhabditida: Steinernematidae)? - Journal of Agrobiology 27: 19-25.

[105] Razia, M., Sivaramakrishnan, S. (2014): Isolation and Identification of Entomopathogenic Nematodes of Kodaikanal Hills of South India. - International Journal for Current Microbiology and Applied Sciences 3: 693-699.

[106] Reddy, G. V., Tangtrakulwanich, K., Wu, S., Miller, J. H., Ophus, V. L., Prewett, J. (2014): Sustainable management tactics for control of Phyllotreta cruciferae (Coleoptera: Chrysomelidae) on canola in Montana. - Journal of Economic Entomology 107: 661-666.

[107] Safdar, H., Javed, N., Khan, S. A., Arshad, M. (2018): Reproduction potential of entomopathogenic nematodes on armyworm (Spodoptera litura). - Pakistan Journal of Zoology 50: 1-4.

[108] Salari, E., Karimi, J., Sadeghi-Nameghi, H., Hosseini, M. (2015): Efficacy of two entomopathogenic nematodes Heterorhabditis bacteriophora and Steinernema carpocapsae for control of the leopard moth borer Zeuzera pyrina (Lepidoptera: 
Cossidae) larvae under laboratory conditions. - Biocontrol Science and Technology 25: 260-275.

[109] Saleh, M. (2017): Efficacy of entomopathogenic nematodes against Lepidoptran insect pests. - In: Abd-Elgawad, M., Askary, T., Coupland, J. (eds.) Biocontrol agents: entomopathogenic and slug parasitic nematodes. CABI, Wallingford, UK.

[110] Saleh, M., Metwally, H. M., Mahmoud, Y. (2018): Potential of the entomopathogenic nematode, Heterorhabditis marelatus, isolate in controlling the peach fruit fly, Bactrocera zonata (Saunders) (Diptera: Tiphritidae). - Egyptian Journal of Biological Pest Control 28: 1-6.

[111] Shapiro-Ilan, D. I., Gouge, D. H., Koppenhöfer, A. M. (2002): Factors Affecting Commercial Success: Case Studies in Cotton, Turf and Citrus. - In: Gaugler, R. (ed.) Entomopathogenic nematology. CABI, New York.

[112] Shapiro-Ilan, D. I., Gouge, D. H., Piggott, S. J., Fife, J. P. (2006): Application technology and environmental considerations for use of entomopathogenic nematodes in biological control. - Biological Control 38: 124-133.

[113] Shapiro-Ilan, D. I., Cottrell, T. E., Mizell III, R. F., Horton, D. L., Behle, R. W., Dunlap, C. A. (2010): Efficacy of Steinernema carpocapsae for control of the lesser peachtree borer, Synanthedon pictipes: Improved aboveground suppression with a novel gel application. - Biological Control 54: 23-28.

[114] Shapiro-Ilan, D. I., Han, R., Dolinksi, C. (2012): Entomopathogenic nematode production and application technology. - Journal of Nematology 44: 206-217.

[115] Shapiro-Ilan, D. I., Han, R., Qiu, X. (2014): Production of entomopathogenic nematodes. - In: Morales-Ramos, J. A., Rojas, M. G., Shapiro-Ilan, D. I. (eds.) Mass production of beneficial organisms. Elsevier.

[116] Shields, E., Testa, A., Neumann, G., Flanders, K., Schroeder, P. (2009): Biological control of alfalfa snout beetle with a multi-species application of locally adapted persistent entomopathogenic nematodes: the first success. - American Entomologist 55: 250-257.

[117] Sicard, M., Le Brun, N., Pages, S., Godelle, B., Boemare, N., Moulia, C. (2003): Effect of native Xenorhabdus on the fitness of their Steinernema hosts: contrasting types of interaction. - Parasitology Research 91: 520-524.

[118] Sikandar, A., Zhang, M. Y., Zhu, X. F., Wang, Y. Y., Ahmed, M., Iqbal, M. F., Javeed, A., Xuan, Y. H., Fan, H. Y., Liu, X. Y., Chen, L. J., Duan, Y. X. (2019): Effects of Penicillium chrysogenum strain Snef1216 against root-knot nematodes (Meloidogyne incognita) in cucumber (Cucumis sativus L.) under greenhouse conditions. - Applied Ecology and Environmental Research 17: 12451-12464.

[119] Sikandar, A., Zhang, M., Wang, Y., Zhu, X., Liu, X., Fan, H., Xuan, Y., Chen, L., Duan, Y. (2020a): In vitro evaluation of Penicillium chrysogenum Snef1216 against Meloidogyne incognita (root-knot nematode). - Scientific Reports 10: 8342.

[120] Sikandar, A., Zhang, M., Wang, Y., Zhu, X., Liu, X., Fan, H., Xuan, Y., Chen, L., Duan, Y. (2020b): Review article: Meloidogyne incognita (Root-knot nematode) a risk to agriculture. - Applied Ecology and Environmental Research 18: 1679-1690.

[121] Silva, C. P., Waterfield, N. R., Daborn, P. J., Dean, P., Chilver, T., Au, C. P., Sharma, S., Potter, U., Reynolds, S. E., ffrench-Constant, R. H. (2002): Bacterial infection of a model insect: Photorhabdus luminescens and Manduca sexta. - Cellular Microbiology 4(6): 329-339.

[122] Sobhy, H. M., Abdel-Bary, N. A., Harras, F. A., Faragalla, F. H., Husseinen, H. I. (2020): Efficacy of entomopathogenic nematodes against Spodoptera littoralis (Boisd.) and Agrotis ipsilon (H.) (Lepidoptera: Noctuidae). - Egyptian Journal of Biological Pest Control 30: 1-8.

[123] Solter, L. F., Keena, M., Cate, J. R., McManus, M. L., Hanks, L. M. (2001): Infectivity of four species of nematodes (Rhabditoidea: Steinernematidae, Heterorhabditidae) to the 
Asian longhorn beetle, Anoplophora glabripennis (Motchulsky) (Coleoptera: Cerambycidae). - Biocontrol Science and Technology 11: 547-552.

[124] Spence, K., Stevens, G., Arimoto, H., Ruiz-Vega, J., Kaya, H., Lewis, E. (2011): Effect of insect cadaver desiccation and soil water potential during rehydration on entomopathogenic nematode (Rhabditida: Steinernematidae and Heterorhabditidae) production and virulence. - Journal of Invertebrate Pathology 106: 268-273.

[125] Stuart, R. J., Barbercheck, M. E., Grewal, P. S. (2015): Entomopathogenic nematodes in the soil environment: distributions, interactions and the influence of biotic and abiotic factors. - In: Campos-Herrera, R. (ed.) Nematode Pathogenesis of Insects and Other Pests. Springer, Switzerland.

[126] Sunanda, B., Jeyakumar, P., Jacob, V. (2014): Bioefficacy of different formulations of entomopathogenic nematode Steinernema carpocapsae against diamond back moth (Plutella xylostella) infesting cabbage (Brassica oleracea var. capitata). - Journal of Biopesticides 7: 210-215.

[127] Susurluk, A., Ehlers, R.-U. (2008): Field persistence of the entomopathogenic nematode Heterorhabditis bacteriophora in different crops. - BioControl 53: 627-641.

[128] Toubarro, D., Avila, M. M., Hao, Y., Balasubramanian, N., Jing, Y., Montiel, R., Faria, T. Q., Brito, R. M., Simoes, N. (2013a): A serpin released by an entomopathogen impairs clot formation in insect defense system. - PloS One 8: e69161.

[129] Toubarro, D., Avila, M. M., Montiel, R., Simões, N. (2013b): A pathogenic nematode targets recognition proteins to avoid insect defenses. - PloS One 8: e75691.

[130] Trdan, S., Vidrih, M., Valič, N., Laznik, Ž. (2008): Impact of entomopathogenic nematodes on adults of Phyllotreta spp. (Coleoptera: Chrysomelidae) under laboratory conditions. - Acta Agriculturae Scandinavica Section B-Soil and Plant Science 58: 169175 .

[131] Trdan, S., Laznik, Ž., Bohinc, T. (2020): Thirty Years of Research and Professional Work in the Field of Biological Control (Predators, Parasitoids, Entomopathogenic and Parasitic Nematodes) in Slovenia: A Review. - Applied Sciences 10: 7468.

[132] Ulu, T., Sadic, B., Susurluk, I., Aksit, T. (2015): Virulence of four entomopathogenic nematode species for plum sawfly, Hoplocampa flava L. (Hymenoptera: Tenthredinidae). - ISJ-Invertebrate Survival Journal 12: 274-277.

[133] Wagutu, G. (2017): Efficacy of entomopathogenic nematode (Steinernema karii) in control of termites (Coptotermes formosanus). - Journal of Agriculture, Science and Technology 18: 55-64.

[134] White, G. (1927): A method for obtaining infective nematode larvae from cultures. Science (Washington) 66: 302-303.

[135] Xu, C., De Clercq, P., Moens, M., Chen, S., Han, R. (2010): Efficacy of entomopathogenic nematodes (Rhabditida: Steinernematidae and Heterorhabditidae) against the striped flea beetle, Phyllotreta striolata. - BioControl 55: 789-797.

[136] Yadav, A. K. (2012): Soil moisture effects on the activity of three entomopathogenic nematodes (Steinernematidae and Heterorhabditidae) isolated from Meghalaya, India. Journal of Parasitic Diseases 36: 94-98.

[137] Yan, X., Moens, M., Han, R., Chen, S., De Clercq, P. (2012): Effects of selected insecticides on osmotically treated entomopathogenic nematodes. - Journal of Plant Diseases and Protection 119: 152-158.

[138] Yang, P., Liu, J., Liu, N., Han, R., Zhang, Y., Yu, C. (2000): Field control of the apple fruit moth Carposina nipponensis by using Steinernema carpocapsae nematodes. Natural Enemies Insects 22: 79-82.

[139] Zadji, L., Baimey, H., Afouda, L., Moens, M., Decraemer, W. (2014): Entomopathogenic nematodes prevent the termite pest, Macrotermes bellicosus from reconstructing its nest. - Journal of Nematology 46: 258-259. 